\title{
A model of managerial power in the organization
}

\author{
Andrew J. Templer
}

In this first article in a series of three on power, the concept of managerial power is introduced and a model developed of its operation in the organization. The nature of managerial power is investigated and its importance as a medium of organizational analysis is emphasized. Attention is given to the theoretical requirements of an adequate model of managerial power and the proposed model is evaluated in terms of these criteria requirements. It is shown that an adequate model must cover both macro and micro-levels of analysis. In this article, the focus is on the macro-level application of the power model.

S. Afr. J. Bus. Mgmt 1979, 10:107-111

Hierdie eerste van 'n reeks van drie artikels oor mag, gee ' $n$ inleiding tot die konsep van bestuursmag, en beskryf 'n model van die werking van bestuursmag in die organisasie. Die aard van bestuursmag word ondersoek en die belangrikheid daarvan as hulpmiddel tot organisasie-ontleding word beklemtoon. Aandag word gegee aan die teoretiese vereistes van 'n bruikbare model van bestuursmag, en die voorgestelde model word volgens hierdie kriteria ge-evalueer. Dit word aangetoon dat 'n bruikbare model sowel makro- as mikrovlakke van ontleding moet dek. In hierdie artikel is die klem op die makrovlaktoepassing van die magsmodel.

S.Afr. Tydskr. Bedryfsl. 1979, 10:107 - 111
'(Power) is thus both awful and fragile, and can dominate a continent, only in the end to be blown down by a whisper. To destroy it, nothing more is required than to be indifferent to its threats, and to prefer other goods to those which it promises. Nothing less, however, is required also'.'

\section{Introduction}

Bertrand Russell is reputed to have said: 'The fundamental concept in social science is power, in the same way as energy is the fundamental concept in physics'. ${ }^{2}$ From this point of view power has the same dynamic and driving characteristic in social science as energy has in physics. Certainly it seems difficult to avoid the area of power when investigating any social relationship between individuals, or any institution set up to formalize this relationship. The mass media highlight the power interplay between groups of individuals in the form of such things as trade union power, student power, black power, and so on; thus it should not be surprising that 'managerial power' plays a key role in any consideration of the institutionalized behaviour which takes place within organizations.

This article attempts to accomplish the difficult - if not wellnigh impossible - task of presenting an understandable, yet academically respectable model of managerial power. Power is such a wide-ranging topic affecting just about every facet of organizational life, that definition and integration of material, not to mention measurement, become extremely problematic. It is necessary, however, to attempt this definition because of the need to understand a topic as important as power. The question naturally arises, why is power important?

\section{The importance of power}

Power is important as a basic for organizational analysis for two reasons: firstly, power is a fundamental dynamic force underlying any form of organizational action and effectiveness. To put it another way, if managements are able to get anything at all done, it is because of the amount of power they exercise over both situation and employees - internal and external to the organization. Secondly, by tying individual and system level variables 
together, power is a valuable integrative concept and offers a very open and flexible explanatory system for organizational analysis. In an area as complex as organizational behaviour there is a need for as open and as flexible an explanatory system as possible - it is believed that the concept of power offers this system.

The importance of power is particularly evidenced when considering organization change and effectiveness. Power has to be considered in any attempts to diagnose organizations since the systems in an organization are typically built up to support the beliefs of key power holders. Thus, for example, the managing director of a company typically ensures that power is directed in a way which supports his own values. These values determine not only how much change can take place but also what type of change. It is what the key power holders see as 'effectiveness' that in the end becomes the accepted definition of effectiveness. All organizational action at one stage or another is initiated by power holders and therefore power and authority relations determine the flow of behaviour in organizations. To put it more simply in the words of the well-known adage: 'Them's as has the power makes the rules'.

Finally, it could be suggested that power is important for the fact that once its role in organizations is understood it becomes easier to explain some of the perennial organizational behaviour problems. This applies particularly to the so-called 'dilemma of organizational control', in which the organization requirement of order has to be matched to growing employee demands for a share in decision-making and control. The traditional means of resolving this dilemma has been to set up a formal hierarchical authority system in which employees are encouraged to accept supervision as 'legitimate', in return for some type of reward. The setting up of an authority system may sound excellent in principle, but unless there is agreement on role requirements and the legitimacy of supervision from all organizational participants, the authority system is likely to lack power and to be no solution to the control dilemma. It is a power analysis of the system which will best indicate its effectiveness.

\section{The nature of managerial power}

It is necessary to clarify what is meant by 'power'. Perhaps the best-known definition is that of Robert Dahl: 3.p216 'The Power of A over B is the capacity of A to make $B$ do something he would not have done without the intervention of $A^{\prime}$. It should be seen from this definition that power is a relationship and a process existing between individuals or groups and operating in both directions. Thus a manager has power to the extent that his subordinates actually carry out his wishes.

It is important to distinguish between power and authority $-\mathbf{a}$ distinction critical to any examination of managerial power within the organization. Wieland and Ullrich ${ }^{4}$ propose that power is the potential for influence backed by the means to coerce compliance: whereas authority is legitimage power which accrues by reason of the individual's role in the organization. Authority is not something totally different from power, but is rather a particular form of power, namely normative or legitimate power. It could almost be said that authority is the distinctive power within organizations, but is a risky thing in the sense that it does not automatically accrue to the power holder simply because he is the power holder. Whereas power can be exercised through coercion, authority is very much built up on the basis of shared values and norms and a sense of mutual trust between supervisor and subordinate.

There have been a number of analyses of managerial power that have gone a great deal further than merely distinguishing power and authority, proposing for example, a number of 'bases of managerial power'. ${ }^{9}$ The essential distinction brought out is between 'position power' - depending upon an individual's structural position in the organization; and 'personal power' - dependent upon the individual's personal characteristics and his or her process relationship with subordinates. An adequate model of managerial power will need to include both these structural and the process characteristics of power.

\section{Requirements of a model of managerial power}

A model of managerial power is required which does justice to the complexity of the organizational context, and yet is in a form logical and simple enough to facilitate its utilization. The model will have to consider not only individual differences, but also organizational and environmental differences which together determine the operation of organizational power. Specifically it is suggested that there are three main criteria of an adequate model: to facilitate understanding; to match the complexity of the area; and to have predictive validity.

Clearly the first objective of a model is that it facilitates understanding, that it makes it easier to follow a complex set of relationships by presenting them in a simpler format.

In aiding understanding by a simplified presentation of relationships it is essential, however, that the model remains true to the reality of the area considered. Thus a model of managerial power must match with the complexity of the power relationship within an organizational setting. This means that the model must cover power at a macro-level in which the societal and wider organizational enviroments which set the basic power structure are considered. But it must also consider power at a micro-level - the interpersonal power process between manager and subordinate. Another way of viewing this dual focus is to emphasize that an adequate model has to take into account both the constraints within which managerial power has to be exercised, and the impact of power on organizational effectiveness by way of its influence upon employee behaviour. A really good model of managerial power will be expected to achieve a high level of integration among many relevant variables if it is truly to match with the complex reality of power in organizations.

The third requirement of a model of power is to have predictive validity, that is, it must be useful to the business manager who wants to know what will happen after the model is used to analyze power relationships in an organization. In particular it might be suggested that a model should be able to predict comparative differences in power response between different groups of individuals, and that it be able to predict organizational effectiveness. In the final analysis, this is the real test of 
worthwhileness of a model in the organizational behaviour field.

When it comes to examining the available models of managerial power in the literature it is noticed that most models tend to be limited in focus. There is either a focus at the interpersonal or micro-level of power - mainly in the work of the psychologists, or an emphasis at the macro-level on socio-political variables - mainly in the work of sociologists and political scientists. Thus Jackson and Morgan ${ }^{6}$ and Shetty present excellent micro-level models of managerial power, but do not take the external environment of the organization into account. Wood ${ }^{8}$ gets close to an acceptable model of managerial power in his distinction between process and situational variables, and Bennett ${ }^{9}$ provides a useful general framework, although his primary concern is organizational analysis from the point of view of orientation to work, rather than of managerial power.

\section{The proposed model of managerial power}

From a review of the available frameworks it would appear as if an adequate model could be derived from the broad macro-analysis of Bennett ${ }^{9}$ and the inclusion of the essentially micro focus of Jackson and Morgan ${ }^{6}$. This is the background to the model of managerial power proposed in this article, which appears below in Fig. 1.

It can be seen that the model takes cognisance of both the context and process of managerial power in its macroand micro-levels of analysis. At the macro-level managerial power is conceived of as taking place within a particular organization structure, which in turn is embedded in a particular societal environment. At the microlevel power is conceived of as being a function of a 'psychological contract' between manager and subordinate. The final output of the model is a level of organizational effectiveness indicated by employee performance and satisfaction, and flowing out of the employee response to the perceived consonnance or dissonance in the terms of the psychological contract between manager and subordinate.

A few comments must be made regarding the model. Firstly, it should be noted that only the major flows of power within the model are indicated, i.e. the flow from macro- to micro-level, and from manager to employee. It must be emphasized that in reality power flows in both directions. Thus power can flow from micro- to macrolevel in the effect of individual and organizational variables upon the environment; and power can flow from employee to manager in that the employee is able to exercise considerable power in his relationship with his supervisor.

The macro analytical level of the model includes the environmental variables and the organizational structure variables, and hence has its main point of focus upon the

Environmental variables

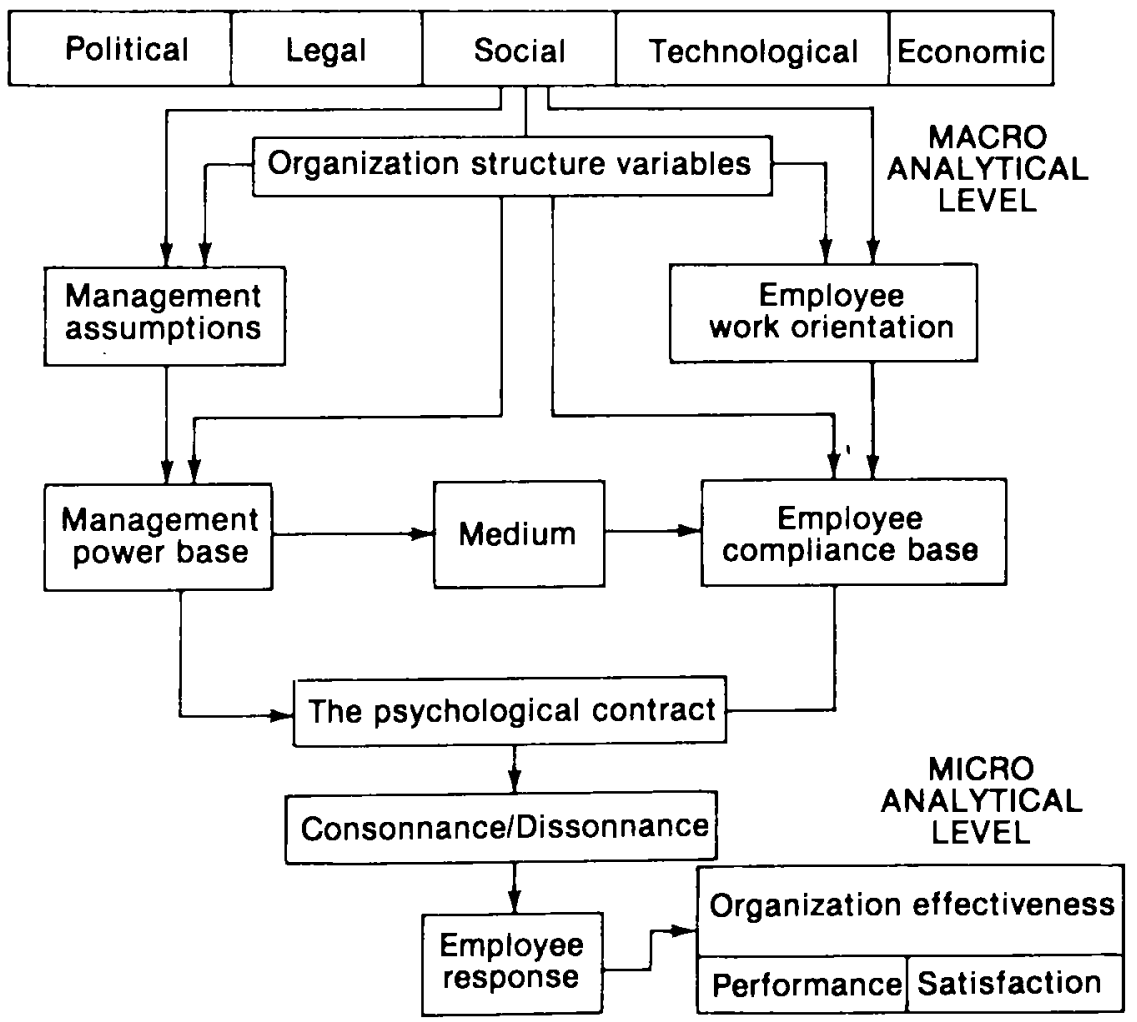

Fg. 1 The model of managerial power. 
structural elements of power. The micro analytical level of the model focusses on the power relationship between manager and employee considering both management power base, medium employed and employee compliance base. Thus at the micro-level the major focus is upon psychological and individual difference variables - the process rather than the structure of power.

It will be noted from the model that two intervening variables are suggested as operating between the macroand micro-level of the model: managerial assumptions; and employee work orientation. These two intervening variables have been included because of their practical and theoretical utility.

In the first place it is necessary to look at the values and assumptions of management - typically the power holders, if any meaningful analysis is to be made of the power base they come to employ. This is because power is both a driving and a directional force, and it is the values of the power holders which determine the direction that power will take.

Secondly, the concept of employee work orientation is of considerable value in linking environmental, organizational and individual levels within the power model. Orientation to work refers to the total set of expectations and goals an individual worker has regarding the work situation. These orientations are as much a product of the employee's environment and organization as they are of his individual different characteristics. Included in these expectations is the type of reward that the employee expects to get out of the work environment, the type of relationships that he expects to encounter, and the importance of work satisfaction in his total life satisfaction concept. Thus in terms of the model, if work is simply not particularly important to an individual employee, it cannot be expected that management will have all that much power over him in the work relationship. On the other hand, an ambitious employee to whom life and work satisfactions are closely associated, will be highly motivated to attain any rewards management has and offer to those who comply with their requests.

The link between the macro or structural element of the model and the micro or process element of the model takes place in the following way: At the micro level it is suggested that power is a relationship between individual manager and individual employee; but this relationship is very much a product of (a) the overall assumptions of management which are determined by societal and organizational factors, and (b) employee work orientation which is also a function of the model's macro level variables.

It is important to point out that the balance and interplay between the structural and process variables of managerial power take place at all levels in the model. Thus while it makes logical sense to suggest that the main focus of structural determinants of power are at the macro level, while the main focus of power process is at the micro level, any tight restriction of variables to any one level would not be true to the reality of organizational power. There are indeed important structural or context variables that operate at the interpersonal level, and also important process variables that operate between an organization and its environment.

When considering an adequate model of managerial power, what is required is a framework which links managerial power with decisions made about goal or work behaviour, within the context of the constraints and opportunities encountered both inside and outside the organization. In essence, it must be a model that embraces the individual, the organization and the environment. It is suggested that the model presented here fulfils these conditions. Before it is possible to conclude the article, however, it is necessary to evaluate the model in terms of the criteria requirements for a model of managerial power that were discussed earlier.

\section{Evaluating the model}

It will be remembered that three main criteria for a model of managerial power were mentioned: That it facilitate understanding, that it match with the complexity of the area, and that it have predictive validity. A brief consideration is given to each of these in turn.

The first requirement of the facilitation of understanding relates to a somewhat subjective judgement and is to some extent subsumed by the other requirements. It is considered that the model is reasonably easy to understand and it is yet to be suggested that it is a just representation of the reality of power, and so has fulfilled this requirement.

The next question to be asked then is, does the model provide an understanding of managerial power as an integrated and complex concept within organizational life? It is felt that this is the case. Power is seen as essentially a relationship between manager and subordinate, which is only fully understood by referring to the wider societal and organizational environment in which it takes place. The model shows the interrelationship between structural and personal variables and makes clear that no understanding can be reached by an exclusive focus at one level. The model has brought about an integration of environmental, organizational and individual variables, thus achieving the link between organization structure and humanistic psychology that such authors as Ouchi and Johnson ${ }^{10}$ call for. In its structural emphasis the model does take into account static conceptions of power; whereas in its psychological contract the model also includes the necessary complementary dynamic conceptions.

In summary then, it is felt that the model accords with complex reality in that it satisfies the key criteria suggested by Shepard and Hougland ${ }^{11}$ that an adequate understanding of organizational behaviour is achieved only by conceptions which take account not only of individual differences (a 'complex man' viewpoint), but also organizational and environmental differences (a 'complex organization' viewpoint).

The final question to be answered is whether the model has predictive validity, whether it offers the means of predicting comparative differences and then organizational effectiveness.

Turning first to comparative differences the basic question at issue is whether the model of managerial power is able to provide a basis for explaining the behavioural differences in response to power between different groups of employees. Particularly in a model of power in the South African environment one would want to be able to point to academically respectable reasons for observed dif- 
ferences between black and white employees, to enable the more effective utilization of both these groups in organizations, and to increase their own job satisfaction. It is considered that the model makes a major contribution in being able to distinguish between various possible antecedents of individual differenes. The model distinguishes societal and organizational variables, structural and personal variables, and process and outcome variables, and so makes comparative difference prediction a possibility.

Thus the model would predict, for example, that if one group of employees is faced by a different structural pattern of power from another group, they would certainly show a different behavioural response to managerial power than the other group. Similarly the model would predict that if one group of employees experienced a different management policy from another group, the terms of the psychological contract for the two groups would be different, and hence again there would be differences in the final behaviour evidenced by the two groups.

It has been shown that the model can predict comparative differences, it now remains to consider its usefulness in predicting organizational effectiveness.

It will be noted from the model that the final output element is organizational effectiveness in terms of the degree to which the organization meets its objectives through the best utilization of its human resources. This is specifically set out in terms of employee satisfaction and performance. The model suggests that this employee response is a function of both the structural power context and the interpersonal relationship between supervisor and subordinate. Organizational effectiveness might well be the result of context, but within a given context the type of power base chosen by a manager influences the type of response he receives, and hence affects effectiveness. In terms of Etzioni's 'congruency' hypothesis $^{12}$ it would be argued that the more effective organizations have a congruent match between the type of power authority their managers use and the type of employee involvement found in each organization. This is because such congruent organizations have a balanced and workable psychological contract. To put it in another way, from the model of managerial power it would be argued that organizational effectiveness is a function of the degree of congruency between management power basis and subordinate motive basis.

\section{Conclusion}

In this article a model has been presented which indicates the dynamics of the power relationship of manager and subordinate within the context of the organizational and societal environment. It was shown that the model, while facilitating understanding, remained faithful to the complex reality of organizational power, and perhaps most important of all, provided a basis for predicting organizational effectiveness in behavioural terms. This is, of course, only a starting point, and it is necessary to actually test the model in organizational analysis. In addition the model needs to be refined and expanded considerably if it is to be used for a closer investigation of the power relationship between manager and subordinate. This is the task of a later article in this series on managerial power.

\section{References}

I TAWNEY, R.H. Equality. Allen \& Unwin, London, 1939, pp. $15-16$.

2 HICKS, H.G. \& GULLETT, C.R. Organizations: Theory and Behaviour. McGraw-Hill, New York, 1975, pp. 6-7.

3 CROZIER, M. The problem of power. Soc. Res. 40, 1973, pp. $221-228$.

4 WIELAND, G.F. \& ULLRICH, R.A. Organizations: Behaviour, Design and Change. R.D. Irvin Inc., Homewood, Illinois, 1976, pp. $265-310$.

5 FRENCH, J.R.P. \& RAVEN, B. The bases of social power. In: Group Dynamics, (eds) Cartwright, D. \& Zander, A., Harper \& Row, New York, 1968, pp. $259-269$.

6 JACKSON, J.H. \& MORGAN, C.P. Organization Theory. Prentice-Hall Inc., Englewood Cliffs, New Jersey, 1978, pp. $2657-267$.

7 SHETTY, Y.K. Managerial power and organizational effectiveness. J. Mgmt Studies, 15, 1978, pp. 176-186.

8 WOOD, M.T. Power relationships and group decision-making in organizations. Psychol. Bull., 79, 1973, pp. 280-293.

9 BENNETT, R. Orientation to work and organizational analysis. $J$. Mgmt Studies, 15, 1978, pp. $187-210$.

10 OUCHI, W.G. \& JOHNSON, J.B. Types of organizational control and their relationship to emotional well-being. Admin. Sci. Quart., 23, 1978, pp. $293-317$.

11 SHEPARD, J.M. \& HOUGHLAND, J.G. Contingency theory: 'Complex man' or 'Complex organization' Acad. Mgmi Rev., 3, 1978, pp. $413-427$.

12 ETZIONI, A. A basis for comparative analysis of complex organizations. In: A Sociological Reader on Complex Organizations, (ed) Etzioni, A, Holt, Rinehart \& Winston Inc., New York, 1969 , pp. $59-76$. 